\title{
Weed biological control in California, USA: review of the past and prospects for the future
}

\author{
Michael J. Pitcairn
}

Received: 31 March 2017/Accepted: 23 April 2018/Published online: 5 May 2018

(C) The Author(s) 2018

\begin{abstract}
Weed biological control in California, USA began in 1940 with the release of a native scale insect on native Opuntia spp. on Santa Cruz Island, just offshore from mainland California. Since then, a total 39 weed species have been targets of biological control releases in California. Releases on 11 weed targets were transfer experiments where agents from related weed hosts were released on a new host. Most of the transfer experiment introductions failed but one weed was successfully controlled. Of the other 28 weeds, release sites for three species were destroyed and for six species releases are too recent to score, but for 19 weeds, their level of control was rated as: complete control (three species), substantial control (five species), and partial (six species), and negligible control (five species). Overall, $42 \%$ of the projects provide successful control, a result lower than observed in other countries worldwide. Since 1940, 77 species of agents have been released: 54 species
\end{abstract}

Handling Editors: Mark Schwarzländer, Cliff Moran and S. Raghu.

Electronic supplementary material The online version of this article (https://doi.org/10.1007/s10526-018-9884-6) contains supplementary material, which is available to authorized users.

M. J. Pitcairn ( $\square)$

California Department of Food and Agriculture,

Biological Control Program, 3294 Meadowview Road,

Sacramento, CA 95832, USA

e-mail: mike.pitcairn@cdfa.ca.gov established, 12 species failed to establish, six species had their release sites destroyed, and five species are too early to determine. Establishment rate was $82 \%$ but the rate differed among taxonomic orders. Individual agents were scored according to level of impact on their host and Coleoptera obtained the highest average impact score and Diptera the lowest. Mean impact scores over time showed a substantial drop in the 1980s but later increased. Future research efforts that emphasize introduction of high impact agents will further support development of this critical weed control method for California.

Keywords Weed - Biological control · California · Establishment rate $\cdot$ Success rate

\section{Introduction}

In April 1940, Harry S. Smith, a professor of Entomology at the University of California in Riverside, collected crawlers of native Dactylopius tomentosus (Lam.) (Hemiptera: Dactylopiidae) from local Opuntia spp. near the City of Riverside in southern California, USA carried the live material by boat to Santa Cruz Island, located approximately $32 \mathrm{~km}$ offshore from Santa Barbara County, and liberated them onto two native Opuntia (O. littoralis (Engelm.) Cockerell and $O$. oricola Philbrick (Cactaceae)) (Goeden et al. 1967). This action was the first use of 
a live organism to control a weed in North America. Five years later, the leaf beetle, Chrysolina hyperici (Forster) (Coleoptera: Chrysomelidae), was released on Hypericum perforatum L. (Hypericaceae), an exotic forb that had invaded the pastures and grazing lands in northern California (Holloway 1964). This second action was the first use of an exotic organism to control an exotic weed in North America. Since 1940, 77 species of biological control organisms have been released on 39 weed species in California. The level of control that resulted from some of these releases has been spectacular, such as the reduction of $H$. perforatum (Huffaker and Kennett 1959) following the release of the two Chrysolina leaf beetles. Other projects have failed to result in any meaningful level of control.

Classical biological control is a weed control method where host-specific natural enemies of a weed are introduced from its area of origin to its new area of infestation (Pitcairn 2011). For exotic weeds, this involves the introduction of natural enemies of exotic origin. The intention is for the introduced natural enemy to establish, increase in abundance, and, when successful, cause enough feeding damage to substantially reduce reproduction and recruitment of its host plant. The regional decline of the targeted weed can be dramatic and provides an impressive example of invertebrate consumers controlling a plant's abundance. This paper describes an attempt to compile a complete list of weed biological control projects in California from 1940 through 2015. This review is the first comprehensive record of weed biological control research in California and, for some projects, it is the first published record. The information obtained on the introduction and establishment of biological control agents is summarized and an assessment of the success in reducing the abundance of the weed target and the level of control provided by the established agents is reported.

\section{Materials and methods}

A list of target weeds and the beneficial organisms released in California as biological control agents was compiled by examining published, peer-reviewed literature as well as unpublished technical reports and quarantine records. Some of the releases associated with projects prior to 1990 were summarized in
Turner (1992), Nechols (1995) and Villegas (1998). Details for other projects were obtained in the Annual Reports of the California Department of Food and Agriculture's Biological Control Program and in unpublished records at the USDA Agricultural Research Service's Quarantine Facility in Albany, California and the Quarantine Facility at the University of California, Berkeley. The scientific names and taxonomic classifications of the agents and their weed targets were updated and aligned with Winston et al. (2014). The information was entered into two Microsoft Excel (version 2013) spreadsheets, one with details on the weed targets (Supplementary Table S1) and one with details on the individual agent species (Supplementary Table S2). Summary statistics were generated using the functions of the spreadsheet. In generating these two tables, the following definitions were used.

\section{Target weed species}

For most projects, only one taxonomic entity was identified for each target weed. There are three exceptions: (1) the three Opuntia taxa, O. littoralis, $O$. oricola, and a hybrid of the two, on Santa Cruz Island; (2) Tamarix spp. which, in California, consists of three species: T. chinensis Lour., T. parviflora DC., and $T$. ramosissima Ledeb. (Tamaricaceae) as well as hybrid combinations of all three (Gaskin and Schaal 2003); (3) Centaurea jacea L. (Asteraceae) which consists of three sub-species: $C$. jacea subsp. jacea, $C$. jacea subsp. nigra (L.) Bonnier \& Layens, and $C$. jacea nothosubsp. pratensis (W.D.J. Koch) Čelak. For this analysis, all related taxa within each exception are counted as one target weed entity.

\section{Biological control agent species}

For all agents, only species were counted, different biotypes or other taxonomic entities were not counted separately. For example, two biotypes of Coleophora parthenica Meyrick (Lepidoptera: Coleophoridae) were released against Halogeton glomeratus (M.Bieb.) C.A. May (Chenopodiaceae): one collected from Salsola tragus L. (Chenopodiaceae) and another collected from $H$. glomeratus. For this review, the release of the two $C$. parthenica biotypes on $H$. glomeratus is counted as one agent-target combination. 
Number of introductions

The number of introductions is the unique combination of an agent and a target weed. Some agents were used on more than one weed target and are counted as separate introductions. For example, Rhinocyllus conicus (Frölich) (Coleoptera: Curculionidae) was introduced on Carduus nutans L. (Asteraceae), Carduus pycnocephalus L. (Asteraceae), Onopordum acanthium L. (Asteraceae), and Silybum marianum (L.) Gaertn. (Asteraceae). Each of these were counted as separate agent-target introductions.

\section{Date of introduction}

The year of the first release of an agent is the year for which a project began.

Classical biological control projects and transfer experiments

A classical biological control project typically consists of five steps: (1) identification of the target weed, (2) foreign exploration, (3) host specificity testing, (4) release from quarantine (initial establishment), and (5) post-release monitoring and redistribution. Ideally, the biological control agent is obtained from the target weed in its area of origin and released on the same target species in the area of introduction. In some cases, agents from one weed are released on another closely-related weed species to see if the agent provides some benefits. This is particularly true for agents that have been approved for introduction and there are other noxious weed species closely related to the target weed in the invaded region. For these projects, the related weed species was not examined in its area of origin and the released agents were not obtained from the new target and thereby lack any evolutionary connection and are considered to be "transfer experiments." For example, $R$. conicus was collected from $C$. nutans in Italy and released on $C$. nutans in California where it established. Later, $R$. conicus weevils were collected from $C$. nutans in California and released on O. acanthium in California where it failed to establish. The latter introduction is identified as a transfer experiment. There is one exception: two biotypes of $C$. parthenica were released on $H$. glomeratus, one reared from $S$. tragus and one reared from $H$. glomeratus. Releases of the $S$. tragus biotype occurred in 1974 and 1975 (Dunkle 1975) and in 1976, a single release of the $H$. glomeratus biotype occurred (Dunkle 1977). The focus of the research effort at that time was $S$. tragus and the release of the $H$. glomeratus biotype was a one-time event, so, for this analysis, the H. glomeratus project is considered to be a transfer experiment.

Measures of success, weeds

A common problem in attempting to review the success of weed biological control projects worldwide is the lack of quantitative information on the amount of reduction in the target weed (Crawley 1989; Hoffmann 1995; MacFadyen 2000). California has the same lack of quantitative control information. Only a handful of projects, H. perforatum (Huffaker and Kennett 1959), Jacobae vulgaris Gaertn. (Asteraceae) (Pemberton and Turner 1990), and Chondrilla juncea L. (Asteraceae) (Supkoff et al. 1988) have quantitative before-and-after data on the population abundance of the target weed in California. While these studies are decades old, the lack of resurgence of these weeds does suggest that the results reported may still have some relevance.

Hoffmann (1995) proposed three qualitative categories of project success for weed biological control projects in South Africa: Complete control-when attempts at control are no longer needed in areas where the agents have established, Substantial controlwhere other control efforts are reduced but still required to reduce the target weed to acceptable levels over the whole region infested, and Negligible control-where there has been little or no reduction in weed abundance or the need to control it. For the current analysis, a fourth category is added, Partial control-where there is some evidence of decline in weed abundance in a limited portion of its infested range or in some habitats but other control efforts continue with little reduction in use. This last category is one level up from Negligible control but below Substantial control. It has been included in other retrospective analyses (Burdon and Marshall 1981; Denoth et al. 2002) and is useful in identifying projects that may have received some benefit from the introduction of biological control agents but the amount of reduction has not been sufficient to reduce control efforts by land managers and stakeholders. The success ratings are reported as follows: Complete 
control, 3; Substantial control, 2; Partial control, 1; Negligible control, 0 .

\section{Measures of success, agents}

The impact of a biological control agent on populations of its host plant is dependent on three factors: amount of damage caused by an individual or population unit of an agent, the local abundance of agents per individual host plant, and the regional occurrence of the agent over the area infested by the target weed. The most successful agents are those that build up large populations on their host plant and inflict sufficient damage to cause a reduction in host abundance. Agents that remain scarce in relation to the abundance of their host are unlikely to cause a meaningful reduction in the abundance of their target weed. Here, an assessment of the level of control (impact) provided by each of the established agents is reported. Impact scores for each agent are based on Klein (2011) and modified as follows: Trivial: established but remained low in abundance, throughout the range of its host, Moderate: obtained a moderate level of abundance in a limited area of its host but was low in abundance or absent elsewhere, Considerable: obtained moderate to high levels of abundance in part or all of the infested range but, alone, was not able to reduce host abundance, Extensive: obtained moderate to high levels of abundance that resulted in successful control of its host plant, and Unknown: not enough information is available to make a reasonable decision regarding impact or their release occurred too recently. Agent impact is reported as follows: Trivial, 1; Moderate, 2; Considerable, 3; Extensive, 4; Unknown, U.

\section{Statistics}

Rates of establishment and impact scores are summarized only for those target weeds or agents for which information is available. For some established agents, little or no follow-up has been performed and their level of control is unknown. In calculating average rates and scores, information from species with unknown status are not included.
California as an ecoregion

The state of California is one of 48 contiguous states that make up the United States of America in the central portion of North American continent. The state is located along the western edge of the continent with the Pacific Ocean as its western border. Despite California being a part of a larger landmass, its unique geography (ocean on the west, Sierra Nevada Mountains along the eastern border, the Klamath and Cascade Mountains in the north and the Mojave and Sonoran deserts in the southwest) has isolated much of California from the rest of the continent. For many plant and animal species, these natural geographic barriers have limited long-distance colonization and gene flow from close relatives in neighboring areas and this isolation has resulted in a high level of endemism. For example, 57 species of conifers occur in California, 27 species are endemic and occur nowhere else in North America or the world (Bakker 1971). Overall, it is estimated that $35 \%$ of plant species native to California are endemic (Harrison 2013).

The climate dominating most of California is Mediterranean, a climate that is rare worldwide and occurs in only five other locations: Chile, South Africa, two locations in Australia, and southern Europe. Mediterranean climate has cool, wet winters and hot, dry summers. This unusual climate is further complicated by the extreme length of the summer drought, which lasts longer in California than elsewhere, and by the unusually high summer temperatures. During summer, daytime high temperatures commonly exceed $35^{\circ} \mathrm{C}$ and daytime $\mathrm{RH}$ drops below $10 \%$.

Botanists have divided the world landmass into floristic regions based on the local level of endemism within the dominant plant communities and the possibility of shared evolutionary histories of the constituent species (Takhtajan 1986). Some regions are further divided into floristic provinces and phytogeographers have identified the California floristic province as a distinct area separated from other areas in North America (Takhtajan 1986). As much as $70 \%$ of the California Floristic Province is included in the political boundary of the state of California (Harrison 2013). It is reasonable, then, to consider California its own ecoregion and that the performance of agents and 
the number of successful control projects may not be similar with other areas of North America.

\section{Results}

From 1940 through 2015, 77 species of biological control agents were released on 39 weed targets in California (Supplementary Tables S1 and S2). Some agents were released on more than one target weed (e.g., R. conicus was released on four target weeds) so, in total, 101 unique target-agent introductions occurred during this time period. The weed targets include taxa from 18 families and 12 orders. The family Asteraceae was the most represented with 16 species, followed by Euphorbiaceae (three species), Chenopodiaceae (two species), Fabaceae (two species) and Hypericaceae (two species). The other 13 families (Amaranthaceae, Araceae, Brassicaceae, Cactaceae, Hydrocharitaceae, Lamiaceae, Lythraceae, Plantaginaceae, Poaceae, Pontederiaceae, Salviniaceae, Tamaricaceae, Zygophyllaceae) were represented with one species each. All plant life histories are represented with perennial species the most abundant (22 species), followed by biennial (ten species) and annual (seven species). The most common plant growth form was herbaceous forbs (33 species), followed by shrubs (three species), one grass (Arundo donax L. (Poaceae)), one tree (Tamarix spp. complex) and one target of succulents (Opuntia spp. on Santa Cruz Island). The targeted weed species occurred in a variety of habitats, with rangelands (30 species) and natural areas (24 species) the most common, followed by aquatic habitats (includes riparian species and free-floating aquatic macrophytes) (eight species) and managed pastures and cultivated lands (eight species) (the total exceeds 39 species because some weeds occur in multiple habitats). The number of agents released on an individual targeted weed species ranged from one to seven agents, with the Opuntia spp. on Santa Cruz Island, Centaurea solstitialis L. (Asteraceae), and Centaurea virgata Lam. subsp. squarrosa (Boiss.) Gugler (Asteraceae), each receiving the highest number of agents. The rate of agent establishment by weed target ranged from 0 to $100 \%$. However the majority of targets showed intermediate rates of establishment.
Measures of success, weeds

Of the 39 weed targets on which biological control agents were intentionally released, 11 were identified as transfer experiments where agents were obtained from closely-related exotic weeds (Supplementary Table S1). Most of the transfer experiment introductions failed (establishment rate $=32 \%, \quad 7 /(24-2$ unknowns)). However, the releases on $C$. virgata subsp. squarrosa were very successful, where five of seven agents established and two agents, Larinus minutus Gyllenhal (Coleoptera: Curculionidae) and Bangasternus fausti (Reitter) (Coleoptera: Curculionidae), built up high numbers and resulted in a $99 \%$ reduction in seed production effectively stopping all plant recruitment (Woods and Villegas 2006). In the years following, adult plants have slowly died from other causes and now $C$. virgata subsp. squarrosa is greatly reduced in abundance and no longer considered an economic weed (Woods and Villegas 2006). In evaluating the success of the classical weed biocontrol projects, the 11 weed targets involved in the transfer experiments were removed from consideration.

In total, 28 weeds have been classical weed biological control targets (Table 1). For nine of these targets, success was not evaluated. Three projects, Alternanthera philoxeriodes (Mart.) Griseb. (Amaranthaceae), Hydrilla verticillata (L. f.) Royle (Hydrocharitaceae), and Pistia stratoites L. (Araceae) had each of their study locations destroyed shortly after release of their agents. There are six projects for which releases occurred within the last ten years and not enough time has elapsed to allow evaluation. A total of 19 weeds are considered further and the level of control achieved for each project shows the following results (Table 1): five weeds showed negligible control, six weeds are rated as partial control, five weeds are under substantial control, and three weeds are under complete control (H. perforatum, the Opuntia spp. on Santa Cruz Island, and J. vulgaris). The five weeds under substantial control (Tribulus terrestris L. (Zygophyllaceae), C. nutans, C. juncea, Lythrum salicaria L. (Lythraceae), and Salvinia molesta D.S. Mitch. (Salviniaceae)) are under complete control in some areas of their range, but much less or little control occurs in other areas of their infestation. For example, L. salicaria is under complete control in area of Big Lake and along the Fall River in eastern Shasta County, an area at $41^{\circ}$ latitude 
Table 1 List classical weed biological control targets in California from 1940 to 2015

\begin{tabular}{|c|c|c|c|c|c|c|c|}
\hline \multirow[t]{2}{*}{ Scientific name } & \multirow[t]{2}{*}{ Common name } & \multirow{2}{*}{$\begin{array}{l}\text { Year of 1st } \\
\text { introduction }\end{array}$} & \multirow{2}{*}{$\begin{array}{l}\text { Level of } \\
\text { control }^{\mathrm{c}}\end{array}$} & \multicolumn{4}{|c|}{ Number of Agents ${ }^{\mathrm{d}}$} \\
\hline & & & & $\mathrm{R}$ & $\mathrm{E}$ & $\geq 2$ & $\geq 3$ \\
\hline Ulex europaeus L. & Gorse & 1953 & 0 & 2 & 2 & 1 & 0 \\
\hline Cytisus scoparius (L.) Link & Scotch Broom & 1960 & 0 & 2 & 2 & 1 & 0 \\
\hline Silybum marianum (L.) Gaertn. & Milk Thistle & 1969 & 0 & 1 & 1 & 1 & 0 \\
\hline Salsola tragus $\mathrm{L}$. & Russian Thistle & 1973 & 0 & 2 & 2 & 0 & 0 \\
\hline Eichhornia crassipes (Mart.) Solms & Water Hyacinth & 1982 & 0 & 4 & 3 & 1 & 0 \\
\hline Centaurea solstitialis $\mathrm{L}$. & Yellow Starthistle & 1969 & 1 & 7 & 6 & 1 & 0 \\
\hline Carduus pycnocephalus $\mathrm{L}$. & Italian Thistle & 1973 & 1 & 1 & 1 & 1 & 0 \\
\hline Centaurea diffusa Lam. & Diffuse Knapweed & 1976 & 1 & 4 & 4 & 3 & $0+2 \mathrm{U}$ \\
\hline Salvia aethiopis $\mathrm{L}$. & Mediterranean Sage & 1976 & 1 & 1 & 1 & 1 & $0+1 \mathrm{U}$ \\
\hline Centaurea stoebe $\mathrm{L}$. & Spotted Knapweed & 1993 & 1 & 5 & 5 & $1+1 \mathrm{U}$ & 0 \\
\hline Cirsium vulgare (Savi.) Ten. & Bull Thistle & 1993 & 1 & 1 & 1 & 1 & 0 \\
\hline Tribulus terrestris $\mathrm{L}$. & Puncturevine & 1961 & 2 & 2 & 2 & 2 & 2 \\
\hline Carduus nutans L. & Musk Thistle & 1974 & 2 & 1 & 1 & 1 & 1 \\
\hline Chondrilla juncea $\mathrm{L}$. & Skeletonweed & 1975 & 2 & 4 & $3+1 \mathrm{U}$ & 2 & 1 \\
\hline Lythrum salicaria $\mathrm{L}$. & Purple Loosestrife & 1996 & 2 & 4 & 4 & $1+3 \mathrm{U}$ & 1 \\
\hline Salvinia molesta D.S. Mitch. & Giant Salvinia & 2002 & 2 & 1 & 1 & 1 & 1 \\
\hline Opuntia spp. ${ }^{\mathrm{a}}$ & Prickly Pear Cactus & 1940 & 3 & 7 & 3 & 2 & 1 \\
\hline Hypericum perforatum $\mathrm{L}$. & Klamath Weed & 1945 & 3 & 6 & 5 & 2 & 2 \\
\hline Jacobaea vulgaris Gaertn. & Tansy Ragwort & 1959 & 3 & 3 & 2 & 2 & 2 \\
\hline Cirsium arvense (L.) Scop. & Canada Thistle & 1966 & $\mathrm{TE}$ & 3 & 2 & 0 & 0 \\
\hline Euphorbia esula L. & Leafy Spurge & 2001 & $\mathrm{TE}$ & 3 & 2 & $0+1 \mathrm{U}$ & 0 \\
\hline Tamarix spp. ${ }^{\mathrm{b}}$ & Saltcedar & 2001 & $\mathrm{TE}$ & 2 & $1+1 \mathrm{U}$ & 1 & $0+1 \mathrm{U}$ \\
\hline Linaria dalmatica ssp. dalmatica (L.) Mill. & Dalmatian Toadflax & 2008 & $\mathrm{TE}$ & 1 & 1 & 1 & $0+1 \mathrm{U}$ \\
\hline Arundo donax $\mathrm{L}$. & Giant Reed & 2010 & $\mathrm{TE}$ & 2 & $1+1 \mathrm{U}$ & $0+1 \mathrm{U}$ & 0 \\
\hline Rhaponticum repens (L.) Hidalgo & Russian Knapweed & 2011 & $\mathrm{TE}$ & 2 & $0+1 \mathrm{U}$ & 0 & 0 \\
\hline Alternanthera philoxeroides (Mart.) Griseb. & Alligatorweed & 1964 & NA & 3 & Ex & - & - \\
\hline Hydrilla verticillata (L. f.) Royle & Hydrilla & 1991 & NA & 2 & Ex & - & - \\
\hline \multirow[t]{2}{*}{ Pistia stratiotes $\mathrm{L}$. } & Waterlettuce & 2013 & NA & 1 & Ex & - & - \\
\hline & & & Totals & 77 & $56+4 U$ & $27+6 U$ & $11+5 \mathrm{U}$ \\
\hline
\end{tabular}

For each weed target, the current level of control and the number of agents released, established, and the level of agent impact are reported. Target weeds are listed by order of level of control and year of introduction of first agent

${ }^{a}$ Opuntia littoralis (Engelm.) Cockerell, O. oricola Philbrick, and hybrids between these two species

${ }^{\mathrm{b}}$ Tamarix chinensis Lour., T. parviflora DC., T. ramosissima Ledeb., and hybrids among these species

${ }^{\mathrm{c}}$ Level of control of the target weed: $0=$ negligible control; $1=$ partial control; $2=$ substantial control; $3=$ complete control; $\mathrm{TE}=$ too early to rate; $\mathrm{NA}=$ no information available

${ }^{\mathrm{d}} R$ number of agents released, $E$ number of agents established; $\geq 2$ number of established agents with impact scores 2 and higher (from Supplementary Table S2), $\geq 3$ number of established agents with impact scores 3 and higher (from Supplementary Table S2), $U$ status unknown, Ex agents extirpated

in northern California. However, L. salicaria occurs in several locations further south in California, including tributaries of the Feather River in Butte County, the Kings River in Fresno County, and the Kern River in Kern County. The two Galerucella beetles did not establish in areas of California south of $39^{\circ}$ latitude (e.g., Fresno and Kern counties) because of photoperiod limitations (unpublished data). The beetles did establish in Butte County, a low elevation $(35 \mathrm{~m})$ location approximately $80 \mathrm{~km}$ south of Big Lake, but the growing season begins before and extends after the active period of the beetles, so the plants are able to outgrow the damage (unpublished data). 
Combining the number of weed targets under substantial and complete control, the success rate is $42 \%$ ( $8 / 19$ weed targets). Out of the 58 unique targetagent introductions associated with the 19 classical biological control target weeds (Table 1), $86 \%$ of these introductions resulted in establishment of the agent (49/(58-1 unknown)). Each of the 19 target weeds had at least one agent established. When weed targets are sorted by life history, annual weeds have a lower rate of success (20\% of targets under complete or substantial control) compared to the biennial (60\%) and perennial (44\%) weed targets, a result similar to that reported by Chaboudez and Sheppard (1995) and Straw and Sheppard (1995).

Measures of success, agents

A total of 77 species have been released as weed biological control agents from 1940 through 2015 (Supplementary Table S2). Most species were insects $(n=72)$ but two mite and three fungal species were also released. Species of Coleoptera were the most represented $(n=37)$, followed by Diptera $(n=13)$ and Lepidoptera $(n=12)$. By family, Curculionidae and Chrysomelidae were the most used $(n=17$ and 12 , respectively), followed by Tephritidae $(n=8)$. All other taxonomic families had four or less species introduced. Overall, the establishment rate for agents on at least one target weed was $82 \%$ (54/(77-11(5 unknowns and 6 extirpated))) but rate of establishment differed among orders and families with the Acari (two species), Hymenoptera (one species), and fungi (two species) having the highest rate of establishment $(100 \%)$, followed by Coleoptera (83\%), Diptera (69\%), Hemiptera (67\%), and Lepidoptera (55\%). The release rate averaged 9.7 species per decade with a lower release rate initially and a notable drop in the 1980s (Fig. 1). However, the rate of establishment across decades showed an increasing trend with the highest establishment rate (88\%) obtained in the two most recent full decades (1990-2009). Among the insect and mite biological control agents, 58\% were concealed feeders/borers (including seed-feeding insects), $20 \%$ were chewers, $14 \%$ were sap feeders, and $8 \%$ were gallers. All plant parts were targeted by the agents with $37 \%$ being leaf-feeders, $26 \%$ seed/ flower feeders, $22 \%$ feeding on roots and lower stems, and $15 \%$ feeding on the main/upper part of stems.

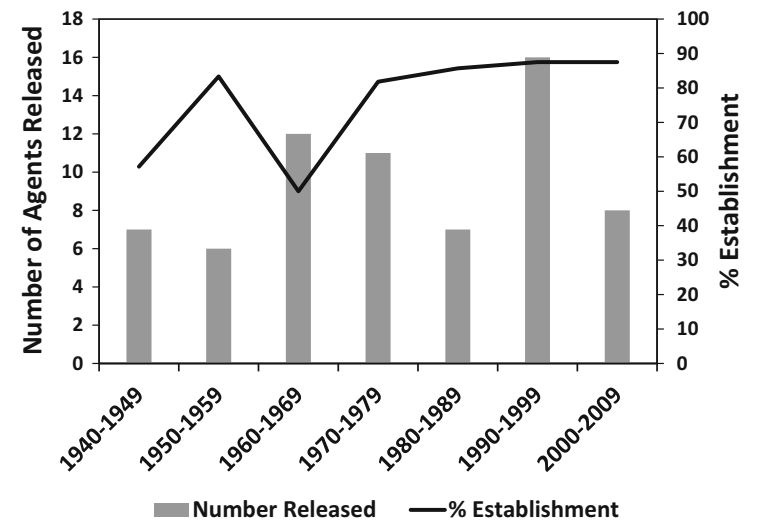

Fig. 1 Numbers of weed biological control agents released and rates of establishment in California by decade

For those agents for which information is available, an assessment of their impact on their host was recorded (Supplementary Table S2). Two associations are of interest. First, the average impact score by order shows the Coleoptera to have the highest average score and the Diptera to have the lowest average score (Fig. 2a). Second, the average impact score of agents released varied by decade (Fig. 2b). Interestingly, the average impact score showed a substantial drop in the 1970 s and 1980s, suggesting that, for the agents released during this time period, little benefit appears to have come from their presence.

The combined impact of the complex of agents that established on each weed target was examined by tallying the number of agents that resulted in impact scores of two or higher and the number of agents having impact scores three or higher (Table 1). The results show that for the 28 classical biological control targets 54\% (27/(56-6 unknowns)) of established agents provided a moderate or higher level of impact on their hosts. Eleven agents are rated with impact scores of three or higher, indicating that $24 \%(11 /(56-$ 11 unknowns)) of the agents that established are considered effective agents and contributed to successful control of their hosts. In a review of international weed biological control projects, Crawley (1989) reported an average of $25 \%$ of established agents to be effective, suggesting that the results in California are similar. 

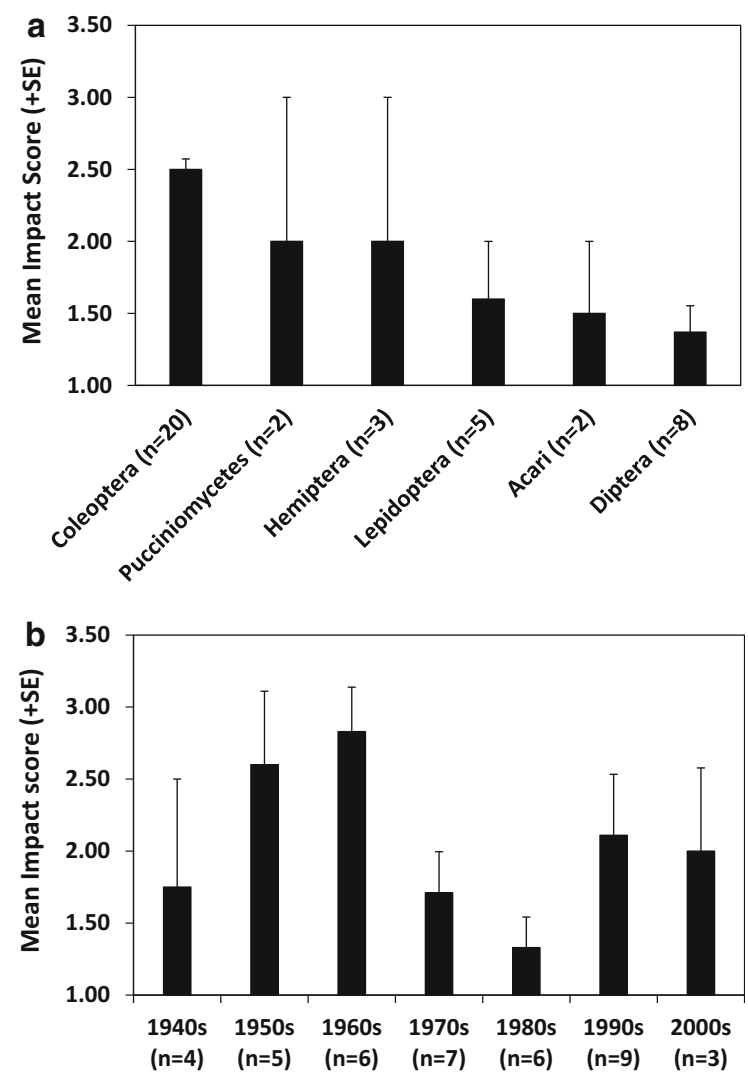

Fig. 2 a Average impact value (+ SE) of weed biological control agents established in California by taxonomic order. Sample size (number of species) is identified in the parentheses. Orders with only one species are not displayed. b Average impact value $(+\mathrm{SE})$ of weed biological control agents released in California by decade. Sample size (number of species) is identified in the parentheses. Values are calculated from individual agent data in Supplementary Table S2

\section{Discussion}

In the 76 years during which beneficial organisms have been released for the biological control of weeds in California, complete control has been obtained for four weeds, H. perforatum, the Opuntia spp. on Santa Cruz Island, J. vulgaris, and $C$. virgata subsp. squarrosa (a transfer experiment), and substantial control has been achieved for an additional five species, $T$. terrestris, $C$. nutans, $C$. juncea, $L$. salicaria, and S. molesta. For each of these projects, the amount of herbicide applied and the costs for control have been substantially reduced, and the level of control provided by the biological control agents has been maintained to date. DeBach (1964) reported that the successful control of Klamath weed in California resulted in a cumulative savings of $\$ 14$ million dollars during 1953 through 1959. In Oregon where J. vulgaris is also considered to be under complete control, it was estimated that the project resulted in an annual savings of more than five million dollars due to reduced losses to livestock, increased productivity of pastures, and reduced herbicide use (Coombs et al. 1996). It is likely that California has reaped similar amounts of economic and environmental benefits from each of these classical weed biological control programs.

Despite these successes, there is much more to accomplish. A total of six weeds are considered under partial control and a further five weeds show little or no control (Table 1). In comparison with weed biological control programs in other countries, the rate of success for California programs (42\%) is low (Table 2). Classical weed biological control programs in Australia, New Zealand, and South Africa have each achieved rates of success (substantial and complete control combined) of over $80 \%$. Interestingly, the rate of establishment of introduced agents and the proportion of agents that are effective in California are similar to that reported for Australia, New Zealand, and South Africa so the reason for the low success rate in California may be due to other factors. Three possible explanations are considered.

The first explanation is that, for many agents, there is a mis-match with climate. The Mediterranean climate which dominates California is unusual worldwide and the lack of agents sourced from a Mediterranean region may contribute to the low success rate and the low impact scores for agents that establish. While many of the weeds targeted for control in California are of European origin, not all weeds occur in the Mediterranean region of Europe. As a result, agents best adapted for California may not be available. In addition, many of the California weed targets also occur in other areas of the USA and Canada, areas which generally have more mesic and temperate climates. During the initial efforts to introduce a new agent to North America, researchers attempt to match the climate of the area of origin with the initial area of introduction. Once established, agents are collected and shipped to other states including California. For example, all of the agents released in California on Centaurea diffusa Lam. (Asteraceae) and Centaurea stoebe L. (Asteraceae) were first established in 
Table 2 Proportion of target weeds under various levels of biological control and overall establishment rate of species introduced as biological control agents reported by country or region (California, Hawaii, USA)

\begin{tabular}{|c|c|c|c|c|c|c|}
\hline \multirow{2}{*}{$\begin{array}{l}\text { Country/ } \\
\text { region }\end{array}$} & \multicolumn{3}{|l|}{ Level of control } & \multirow{2}{*}{$\begin{array}{l}\text { Number of weed } \\
\text { targets }\end{array}$} & \multirow{2}{*}{$\begin{array}{l}\text { Agent establishment rate } \\
(\%)\end{array}$} & \multirow[t]{2}{*}{ References $^{\mathrm{a}}$} \\
\hline & $\begin{array}{l}\text { Negligible }+ \text { partial } \\
(\%)\end{array}$ & $\begin{array}{l}\text { Substantial } \\
(\%)\end{array}$ & $\begin{array}{l}\text { Complete } \\
(\%)\end{array}$ & & & \\
\hline Australia & 20 & 0 & 80 & 15 & 69 & 1,2 \\
\hline New Zealand & 11 & 56 & 33 & 9 & 85 & 3,4 \\
\hline South Africa & 17 & 57 & 26 & 23 & 71 & 2,5 \\
\hline Hawaii & 48 & 14 & 38 & 21 & 61 & 6 \\
\hline California & 58 & 26 & 16 & 19 & 82 & 7 \\
\hline
\end{tabular}

$\overline{{ }^{a} 1}$ Briese (2000), 2 McFadyen (2000), 3 Fowler et al. (2000), 4 Hayes et al. (2013), 5 Klein (2011), 6 Markin et al. (1992), 7 This report

Montana, an area much colder and more temperate than California. Another example is the suite of agents released on Eichhornia crassipes (Mart.) Solms (Pontederiaceae) which were first released in the southeastern USA, an area with a much more humid climate than in California. Having a poor climate match with California may impede the ability of an agent to increase to population densities sufficient to provide successful control.

A second explanation for the low rate of success of weed biological control in California may be a lack of sufficient funding to support a project from beginning to end. Economically, it makes sense to share research costs among states infested by a targeted weed. Also, it makes sense to try agents established in other states first and, if not successful, then search for an agent that may perform better in California. However, taking the next step and pursuing a better agent may be delayed or eliminated altogether by the amount of funding available. Low funding may have also interrupted some of the older projects currently assessed as partial or negligible successes. Stakeholders and funding agencies like to fund the newest, worst weed and when something new comes along, project funding can get re-directed to the new target. It should be noted that, while the number of scientists devoted classical weed biocontrol in the western USA had declined during the last ten years, more recently the number of weed biocontrol scientists in California has increased (Paul Pratt, USDA-ARS Exotic and Invasive Weed Research Unit, personal communication). As a result, several of the older projects, E. crassipes, S. tragus, $C$. scoparius, C. solstitialis, and U. europaeus, are now subjects of renewed research efforts.
A third explanation for the low success rate in California is that too little information is available to make an accurate assessment of impact for some of the established agents despite their presence here for many years. For example, Hylobius transversovittatus (Goeze) (Coleoptera: Curculionidae), a weevil that feeds in the roots of $L$. salicaria, was released at several field sites in California from 1996 through 2001. Field samples at two release sites in 2002 (the first year following cessation of releases) showed $H$. transfersovittatus to be present in four of ten plants and two of ten plants, respectively (Villegas 2003). Unfortunately, there has been no additional monitoring of this agent since then. Similarly, the level of control for some weeds, especially those identified as under partial control, may improve with time or with better quantitative information on the impact of the introduced agents. For example, Coombs et al. (2007) reported that Salvia aethiopis L. (Lamiaceae) is under good control in the sagebrush steppe communities in southeastern Oregon, USA. South of the state border in northeastern California, the results are less clear. In the absence of good quantitative data on host and agent abundance, the biological control of $S$. aethiopis is reported under partial control from discussions with local land managers who report no change in their control efforts toward this species. One benefit of this retrospective analysis is to identify those weed projects for which more information is necessary to better understand the system. It is important to keep in mind that the information provided in this review is a snapshot in time and that it would be beneficial to reassess these projects in the future. 
Biological control researchers have addressed only a handful of the many exotic invasive weeds that infest California. Biological control remains the most costeffective and environmentally-benign method of weed control and pressure to reduce herbicide use will reinforce its use. The last 76 years have produced nine successful projects. The establishment rate for new biological control agents for the last 20 years is very high. Future research efforts that emphasize the release of agents with a good potential for high impact on their host may increase the rate of project success and support further development of this critical weed control method.

Acknowledgements The author thanks Ray Carruthers and John Herr for access to the release records at the USDA-ARS Quarantine Facility at Albany, California; Rachel Winston for help in tracking down some of the old literature on agents released in California; and Nick Mills for comments on an early draft of this manuscript. Lastly, great appreciation is extended to Don Joley, Baldo Villegas, and Dale Woods for their tireless work in the introduction and release of beneficial agents for weed biological control in California.

Open Access This article is distributed under the terms of the Creative Commons Attribution 4.0 International License (http:// creativecommons.org/licenses/by/4.0/), which permits unrestricted use, distribution, and reproduction in any medium, provided you give appropriate credit to the original author(s) and the source, provide a link to the Creative Commons license, and indicate if changes were made.

\section{References}

Bakker ES (1971) An island called California. University of California Press, Berkeley

Briese DT (2000) Classical biological control. In: Sindel BM (ed) Australian weed management systems. R.G. and F.J. Richardson Publishers, Melbourne, pp 161-192

Burdon JJ, Marshall DR (1981) Biological control and the reproductive mode of weeds. J Appl Ecol 18:649-658

Chaboudez P, Sheppard AW (1995) Are particular weeds more amenable to biological control? - a reanalysis of mode of reproduction and life history. In: Delfosse ES, Scott RR (eds) Proceedings of the VIII international symposium on biological control of weeds, pp 95-102

Coombs EM, Radtke H, Isaacson DL, Snyder SP (1996) Economic and regional benefits from the biological control of tansy ragwort, Senecio jacobaea, in Oregon. In: Moran VC, Hoffmann JH (eds) Proceedings of the IX international symposium on biological control of weeds, pp 489-494

Coombs EM, Miller JC, Andres LA, Turner CE (2007) Biological control of Mediterranean sage (Salvia aethiopis) in Oregon. In: Julien MH, Sforza R, Bon MC, Evans HC,
Hatcher PE, Hinz HL, Rector BG (eds) Proceedings of the XII international symposium on biological control of weeds, pp 521-527

Crawley MJ (1989) The successes and failures of weed biocontrol using insects. Biocontrol News Inf 10(3):213-223

DeBach P (1964) The scope of biological control. In: DeBach P (ed) Biological control of insect pests and weeds. Reinhold Publishing Co., New York, pp 3-20

Denoth M, Frid L, Myers JH (2002) Multiple agents in biological control: improving the odds? Biol Control 24:20-30

Dunkle RL (1975) 1975 Annual report, biological control services project. California Department of Food and Agriculture, Sacramento

Dunkle RL (1977) 1977 Annual report, biological control services project. California Department of Food and Agriculture, Sacramento

Fowler SV, Syrett P, Hill RL (2000) Success and safety in the biological control environmental weeds in New Zealand. Austral Ecol 25:553-562

Gaskin JF, Schaal BA (2003) Molecular phylogenetic investigation of US invasive Tamarix. Syst Bot 28(1):86-95

Goeden RD, Fleschner CA, Ricker DW (1967) Biological control of prickly pear cacti on Santa Cruz Island, California. Hilgardia 38(16):579-606

Harrison SP (2013) Plant and animal endemism in California. University of California Press, Berkeley

Hayes L, Fowler SV, Paynter Q, Groenteman R, Peterson P, Dodd S, Bellgard S (2013) Biocontrol of weeds: achievements to date and future outlook. In: Dymond JR (ed) Ecosystem services in New Zealand-conditions and trends. Manaaki Whenua Press, Lincoln, pp 375-385

Hoffmann JH (1995) Biological control of weeds: the way forward, a South African perspective. In: BCPC symposium proceedings No 64: weeds in a changing world, pp 77-89

Holloway JK (1964) Projects in biological control of weeds. In: DeBach P (ed) Biological control of insect pests and weeds. Chapman and Hall, London, pp 650-670

Huffaker CB, Kennett CE (1959) A ten-year study of vegetational changes associated with biological control of Klamath weed. J Range Manag 12(2):69-82

Klein H (2011) A catalogue of the insects, mites and pathogens that have been used or rejected, or are under consideration, for the biological control of invasive alien plants in South Africa. Afr Entomol 19(2):515-549

Markin GP, Lai PY, Funasaki GY (1992) Status of biological control of weeds in Hawai' $i$ and implications for managing native ecosystems. In: Stone CP, Smith CW, Tunison JT (eds) Alien plant invasions in native ecosystems of Hawaii: management and research. Cooperative National Park Resources Studies Unit, University of Hawaii, Manoa, pp 466-482

McFadyen REC (2000) Successes in biological control of weeds. In: Spencer NR (ed) Proceedings of the X international symposium on biological control of weeds, pp 3-14

Nechols JR (1995) Biological control in the western United States. University of California, Division of Agriculture and Natural Resources, Oakland, CA, Publication 3361

Pemberton RW, Turner CE (1990) Biological control Senecio jacobaea in northern California, an enduring success. Entomophaga 35(1):71-77 
Pitcairn MJ (2011) Biological control, of plants. In: Simberloff D, Rejmanek M (eds) Encyclopedia of biological invasions. University of California Press, Berkeley, pp 63-70

Straw NA, Sheppard AW (1995) The role of plant dispersion pattern in the success and failure of biological control. In: Delfosse ES, Scott RR (eds) Proceedings of the VIII international symposium on biological control of weeds, pp 161-168

Supkoff DM, Joley DB, Marois JJ (1988) Effect of introduced biological control organisms on the density of Chondrilla juncea in California. J Appl Ecol 25(3):1089-1095

Takhtajan A (1986) Floristic regions of the world. University of California Press, Berkeley

Turner CE (1992) Biological approaches to weed management. In: Beall T (ed) Beyond pesticides: biological approaches to pest management in California. University of California, Division of Agriculture and Natural Resources, Publication Number 21512, pp 32-67

Villegas B (1998) Implementation status of biological control of weeds in California. In: Woods DM (ed) Biological control program annual summary, 1997. California Department of Food and Agriculture, Plant Health and Pest Prevention Services, Sacramento, pp 35-38
Villegas B (2003) Progress on the biological control program against purple loosestrife. In: Woods DM (ed) Biological control program annual summary, 2002. California Department of Food and Agriculture, Plant Health and Pest Prevention Services, Sacramento, p 38

Winston RL, Schwarzlander M, Hinz HL, Day MD, Cock MJW, Julien MH (2014) Biological control of weeds-a world catalogue of agents and their target weeds, $5^{\text {th }}$ Edn. USDA Forest Service, Forest Health Technology Enterprise Team, Morgantown, West Virginia, USA, FHTET-201404

Woods DM, Villegas B (2006) Biological control of squarrose knapweed in northern California: a developing success story? In: Hoddle MS, Johnson MW (eds) Proceedings of the $5^{\text {th }}$ California conference on biological control, Riverside, CA, pp. 66-70

Michael J. Pitcairn is a scientist with the California Department of Food and Agriculture working on the classical biological control of invasive weeds. 